\title{
ARCHITECTURAL ELEMENTS OF A ROYAL RESIDENCE 15th century stone carvings in Tata Castle
}

\section{OLIVÉr GILLICH ${ }^{1}$}

Hungarian Archaeology Vol. 10 (2021), Issue 2, pp. 38-46. https://doi.org/10.36338/ha.2021.2.1

Being an important historical monument and a popular tourist destination, Tata Castle in Komárom-Esztergom County is well-known for many people. The medieval castle rising on the shore of the picturesque Old Lake offers outstanding scenery for its visitors. Although the castle had an important representative role during late medieval times and its archaeological excavation was conducted half a century ago, historians have made few efforts to research the building history and representative function of the castle more thoroughly. In its current state, the castle reveals little of its original 15 th century appearance. However, a detailed examination of the remaining walls and stone carvings can help us to better understand the castle's history.

Keywords: Tata, castle, 15th century, royal representation, stone carvings, window frame, balustrade

\section{THE HISTORY OF TATA CASTLE}

According to our current knowledge, the castle was built in the first decade of the 15th century, during the reign of Sigismund of Luxembourg (1387-1437) (B. SZATMÁRI 1975, 276). With its four corner towers and a regular, almost square-shaped layout (Fig. 1), the castle bears the characteristic features of a Decorated Gothic monument (B. SzATMÁri 1974, 47). Tata Castle later functioned as a royal residence and became a

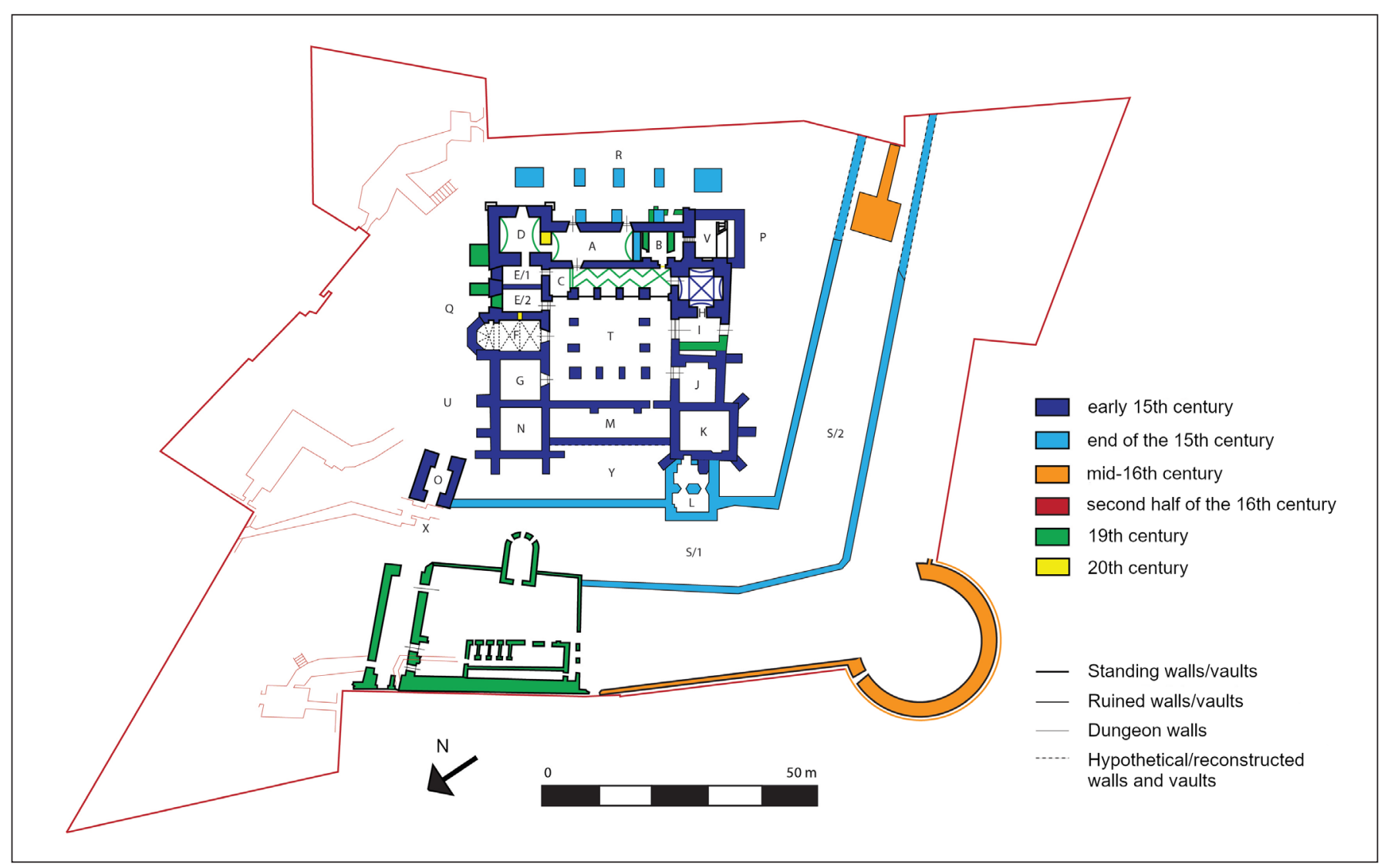

Fig. 1. The floor plan of Tata Castle (after B. SzATMÁRI 1975)

E-mail: gillich.oliver@gmail.com 
Olivér Gillich • Architectural Elements of a Royal Residence. 15th Century Stone Carvings in Tata Castle

favoured place for King Sigismund, who, according to the itinerary that listed the king's known places of stay, spent his time here for longer and shorter periods several times each year (ENGEL \& C. Tóth 2005, 89-130). However, after owning it for one and a half or two decades, Sigismund faced financial difficulties and was forced to pledge the castle during the 1420s to count István Rozgonyi Sr., the head of Temes county (ENGEL 1977, 161). Tata castle remained in the possession of the Rozgonyi family for around half a century (SchmidtMayer 2012, 123-140). The exact date is unknown, but written records indicate that around the beginning of the 1470s, Matthias Corvinus (Mátyás Hunyadi, 1458-1490) took possession of the castle, which once again functioned as a royal residence. In contrast to his predecessor, King Matthias spent less time in Tata, as documented by his itinerary (HoRvÁth 2011, 62-131). Following the death of Matthias, Tata castle belonged to his illegitimate son, John Corvinus, for a short period. At the turn of 1492-1493, Vladislaus II (Jagiellon) (1490-1516) acquired the castle, thus returning it to the hands of the monarch once again. The castle became more important during his reign, especially when the National Assembly held its 1510 meeting in Tata (C. То́тн 2010, 16). The second construction period of the castle was during the second half of King Matthias' reign and the first half of Vladislaus II's rule. No radical changes were made to the layout during this time, as the castle was only reinforced (Fig. 1). A square-shaped building was added in front of the north-western corner tower (marked with "L" in Fig. 1), along with the outer and inner walls surrounding the moat. These inner walls were joined to the formerly mentioned square-shaped structure. A building supported by eight pillars and identified as hanging gardens was built at the lakeside facade of the castle (marked with “R”; Fig. 1) (B. SzATMÁri 1974, 47, 52).

The period following the Battle of Mohács (1526) was particularly difficult for Tata castle, as it endured several sieges in a few decades. It also lost its importance and function as a royal residence and was inducted in the newly formed frontier fortress system. As a result of several sieges and reconstructions, the medieval castle suffered extensive damage in the second half of the 16th century (SCHÖNERNÉ 1968; TóTH 1998), which is visible on Georg Hoefnagel's engraving from 1600 (Fig. 2). The Eszterházy family gained ownership of the castle in the 18th century. They demolished the northern, eastern, and western wings, while the building rubble was used to fill up the inner moat. Only the southern wing escaped demolition (Figs 3-5) (B. SZATMÁri 1974, 48) and was rebuilt twice in the 19th century (ERDEI 1971, 80).

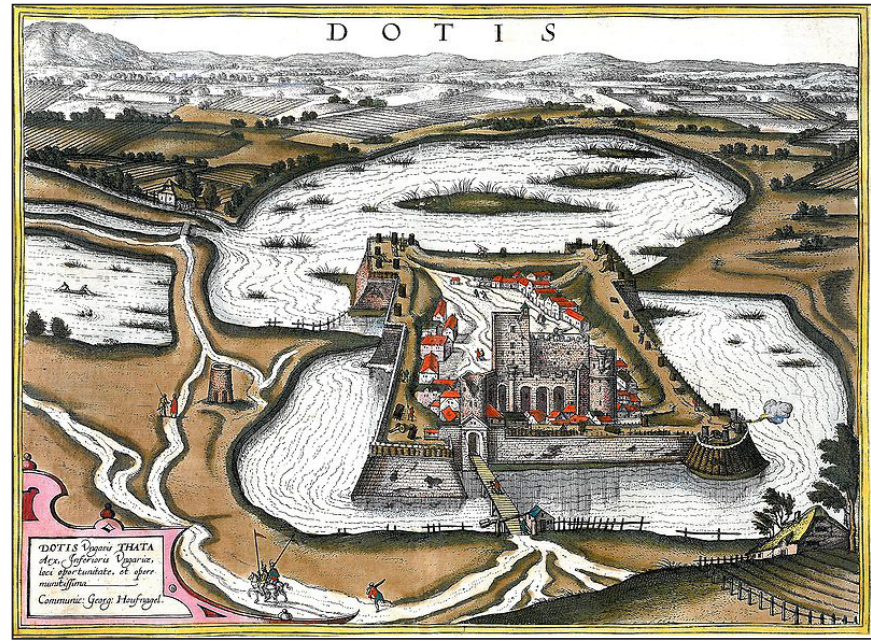

Fig. 2. Georg Hoefnagel's etching of the castle, 1600 (source: keptar.niif.hu)

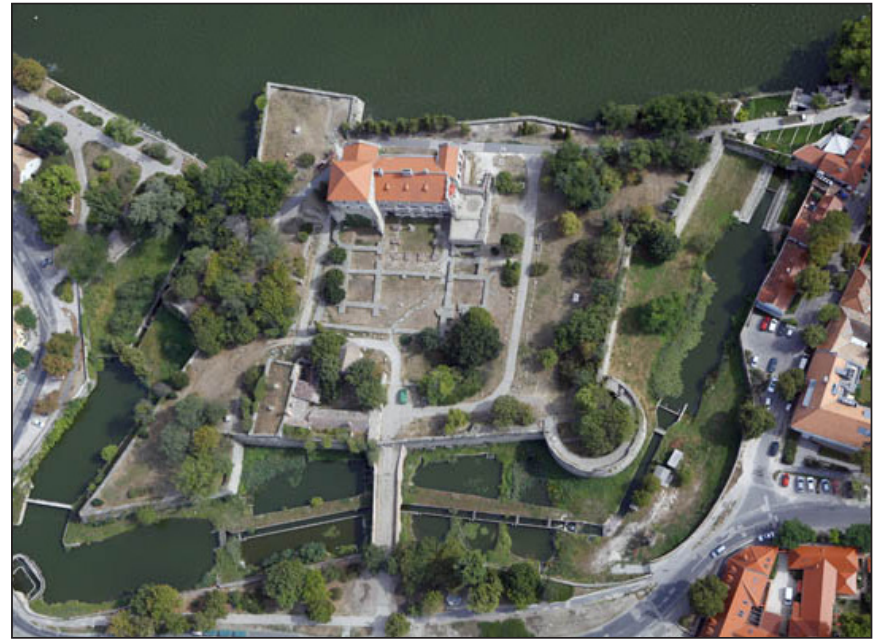

Fig 3. The castle from a bird's eye view (source: legifelvetel.hu)

\section{RESEARCH HISTORY}

The archaeological research of the castle's demolished parts was conducted between 1965 and 1972 (B. SzATMÁRI 1974, 45-53). The excavation revealed the exact layout of the castle, but it was also identified that the walls of the eastern, northern and western wings were demolished almost completely up to the rock surface during the 18th century landscaping (B. SzATMÁRI 1974, 46). While these sections were sunken, the 
Olivér Gillich • Architectural Elements of a Royal Residence. 15th Century Stone Carvings in Tata Castle

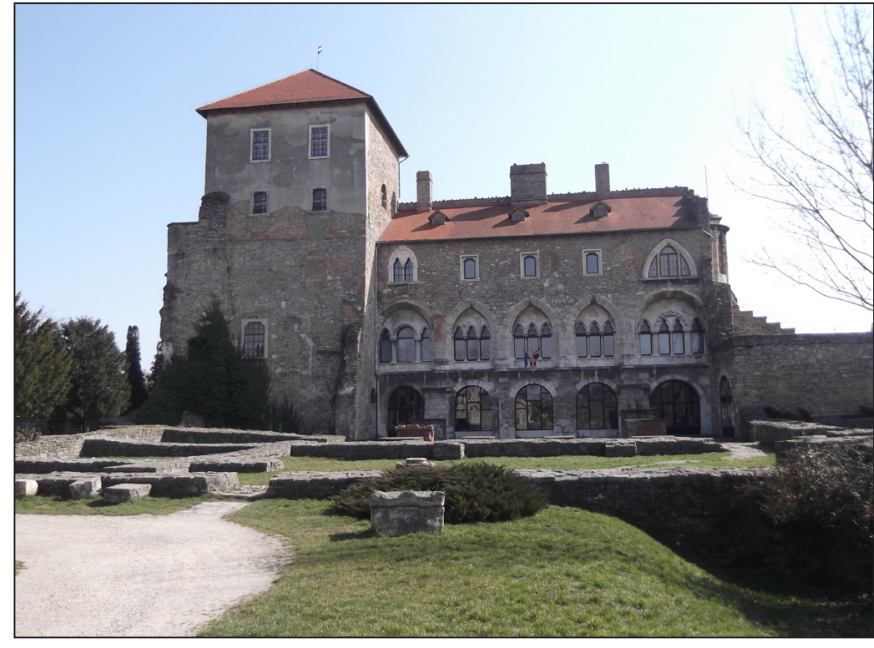

Fig. 4. The northern (inner) facade of the one-time southern wing of Tata Castle (Photo by O. Gillich)

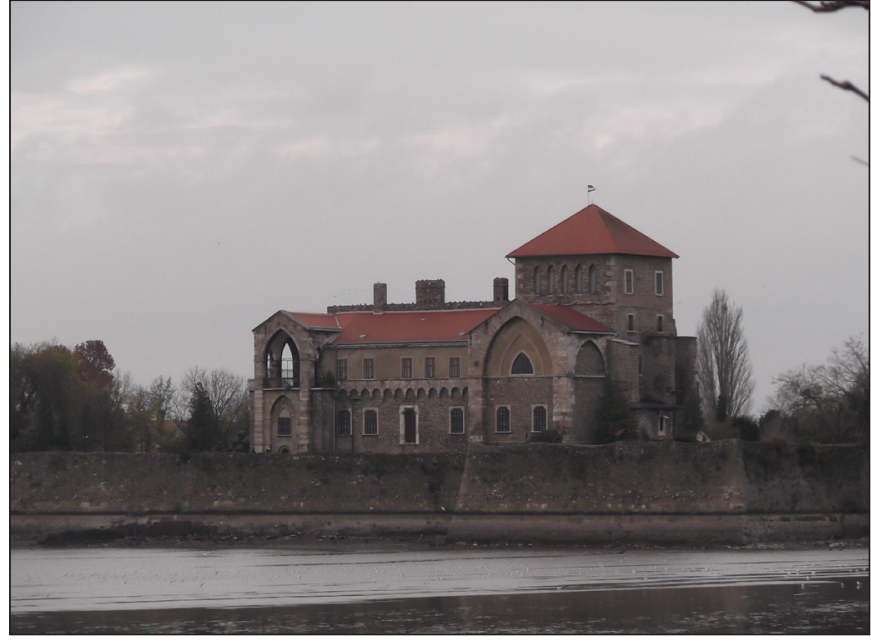

Fig. 5. The castle's view from the lake (Photo by O. Gillich)

area between the southern castle wing and the Old Lake was filled up (marked with "R" in Fig. 1) in the 19th century, thus elevating the surface level by several meters (Excavation report 1969). Only the northern wing's cellar (marked with "M" in Fig. 1), the north-western part of the inner moat (marked with "S" in Fig. 1) and other areas not affected by previous landscaping activities (marked with "P", "Q", and "U" in Fig. 1) provided archaeological finds in large numbers, including stone carvings (Excavation reports 1965-1972). The renovation of the southern castle wing was also done during the excavation period. The removal of the plaster coating uncovered several walled-up medieval windows and doors in their original location, many of which were taken out and renovated (Excavation report 1969-1971). One of the most important archaeological observations was also made during this period: the tower that can be seen today (marked with "E" in Fig. 1) was erected in the 19th century, but its northern wall section, which formerly functioned as the southern wall of the two-storey castle chapel, has medieval origins (Fig. 4). It is particularly fortunate that the religious building's structure can be identified on the wall, making it the highest original wall of the castle (BuZÁs 2010, 94).

\section{MEDIEVAL STONE CARVINGS AND POSSIBILITIES OF THEIR RECONSTRUCTION}

The medieval construction phases of Tata Castle can only be reconstructed by inspecting parts of the southern castle wing and the stone carving fragments that were uncovered during the archaeological survey. Several medieval doors and window frames are visible in the southern wing in their original locations, either as fragments or in renovated condition. Most of these originate from the above mentioned two building periods in the 15 th century. Their exact building dates could be determined by comparing them to segments from other royal residence constructions in the Medium Regni (primarily from the castles of Buda and Visegrád). The same method can be applied to vaults used for covering different areas.

More than 200 stone carving fragments were uncovered during the excavations conducted in the 1960s and 1970s. The majority of archaeological finds include Decorated and Late Gothic elements, there are only two dozen Early Renaissance fragments. Most fragments are from Gothic door or window frames and vault elements. Although fewer in number, parapet fragments, corbels, different architectural capitals, and plinths are also an important group of finds. Based on these fragments, I managed to draw several theoretical reconstructions: the eastern main gate, the chapel's western gate, two sectioned Gothic window frames, a Late Gothic $2 \times 2$ window and two parapets. I would like to introduce the most representative of these (main gate, $2 \times 2$ window, parapets), showing some decorative details of the castle's former appearance. The Renaissance balustrade should also be mentioned, since it is not only a theoretical reconstruction, as the structure was remade using the original fragments (BuZÁs 2008; BuZÁs 2010, 107-108). 
Olivér Gillich • Architectural Elements of a Royal Residence. 15th Century Stone Carvings in Tata Castle

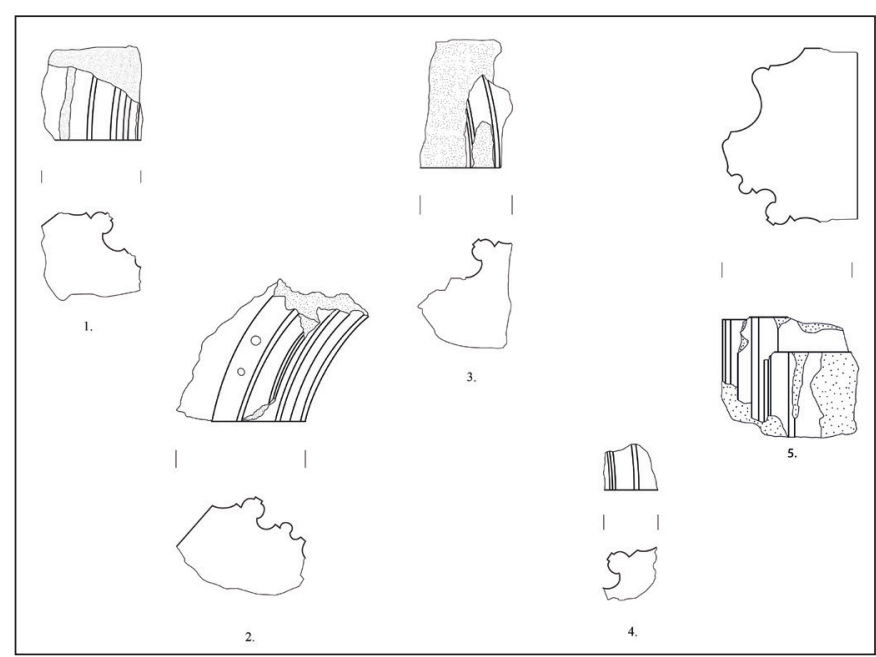

Fig. 6. Carvings of the main gate

During the 1968 excavation, several large stone carvings with an ornate banded profile (Fig. 6) were uncovered near the castle's eastern facade, on the southern part of the territory (marked with "Q" in Fig. 1) (Excavation report 1968). Based on their profiles, it could be determined that the fragments (with the exception of one piece) belonged to the same opening frame (Fig. 7), which was none other than the former main gate of the castle. This theory is further supported by Giulio Turco's castle layout drawing from 1569 (Fig. 8) (SCHÖNERNÉ 1968, 263), on which the entrance is marked south of the castle chapel, i.e., the same place where the carved stone fragments were uncovered. It is also fortunate that the 18th century landscaping did not affect this small area within the castle grounds. As a result, several stone carvings remained intact and could be excavated near the original location of the main gate. The former entrance was closed down and walled-up at an unknown time, meaning that there are no traces of it on the outer wall surface (Fig. 9). As of today, five excavated stone carvings can be linked to this part of the castle. Four of these belong to arched sections, while the last one was from a linear stone layer. The theoretical reconstruction of the main gate could be made with the help of these finds. I made two versions, as at first a semi-circular arched headed gate seemed like the most probable solution (Fig. 10), however, a pointed arch should not be ruled out either (Fig. 11). The original size of the main gate cannot be determined based on these finds, only one piece of data can be estimated: the semi-circular arch and the pitch of the fragment suggest that the width of the main gate was between 1.6

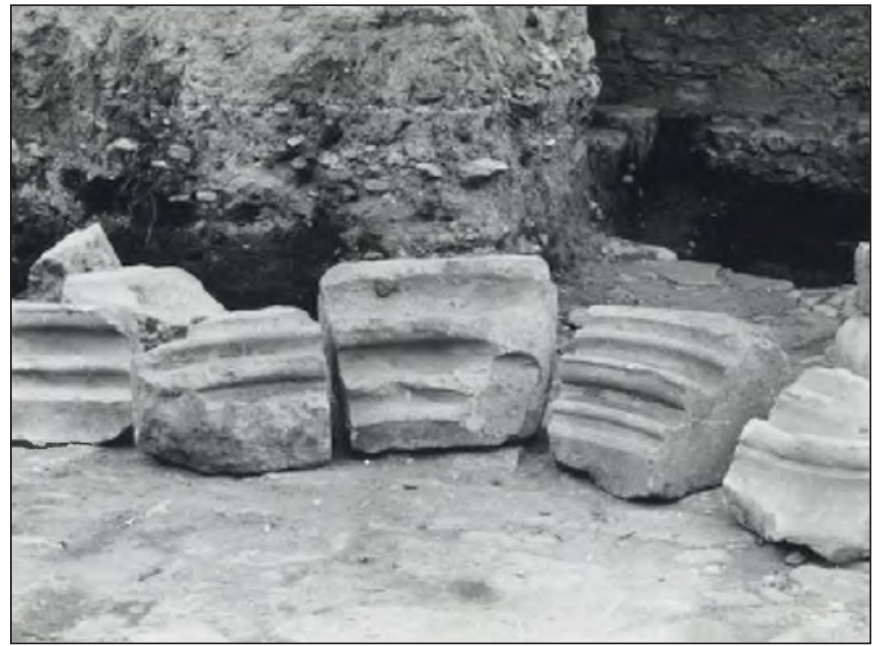

Fig. 7. Carvings of the main gate after they were found in 1968

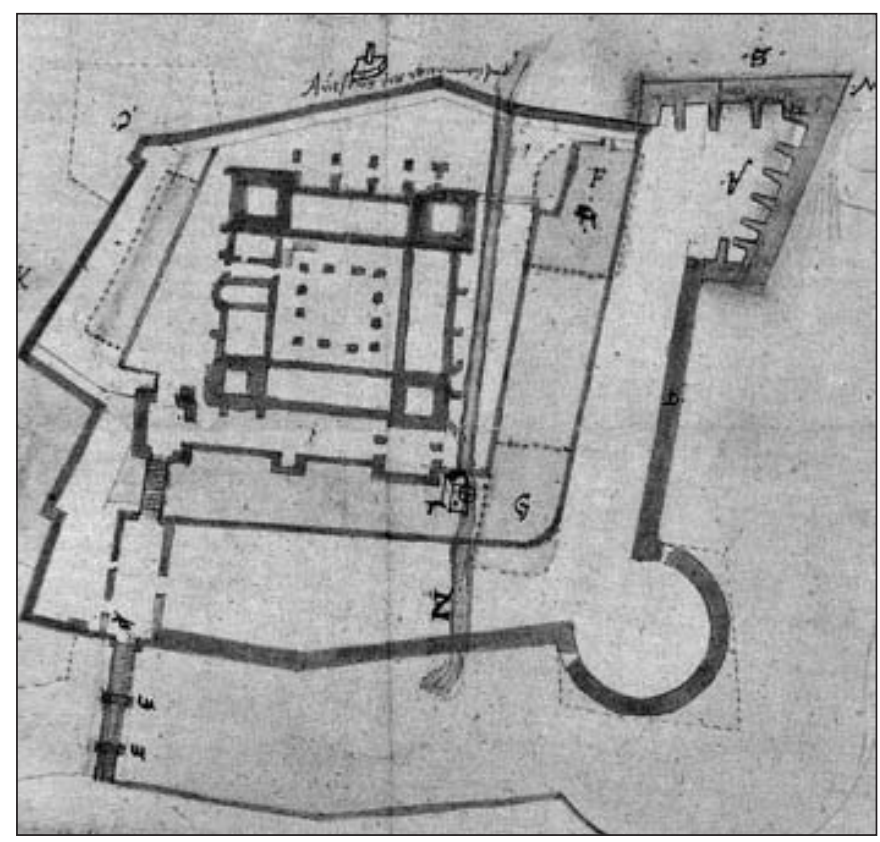

Fig. 8. Giulio Turco's 1569 survey (SCHÖNERNÉ 1968, 263)

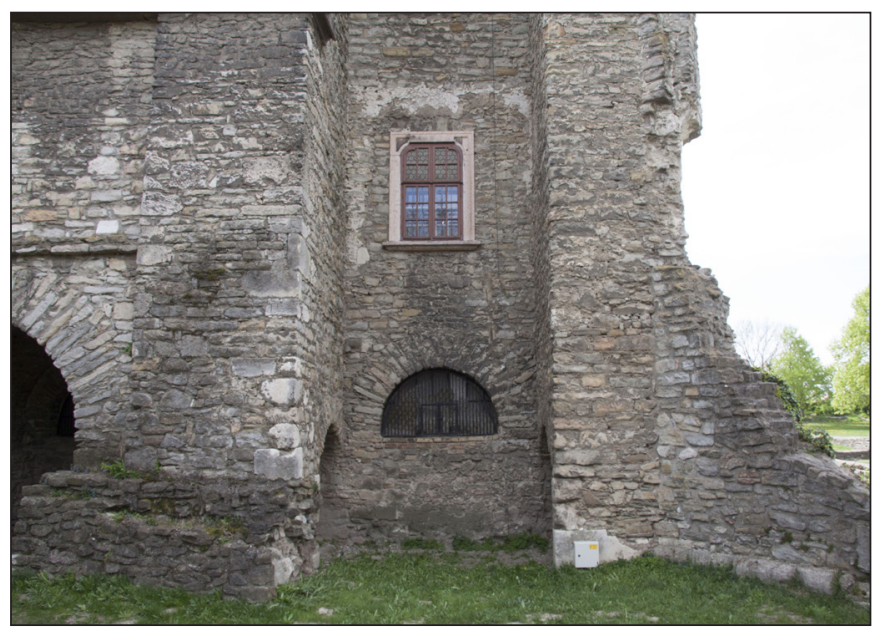

Fig. 9. The hypothetical location of the main gate 


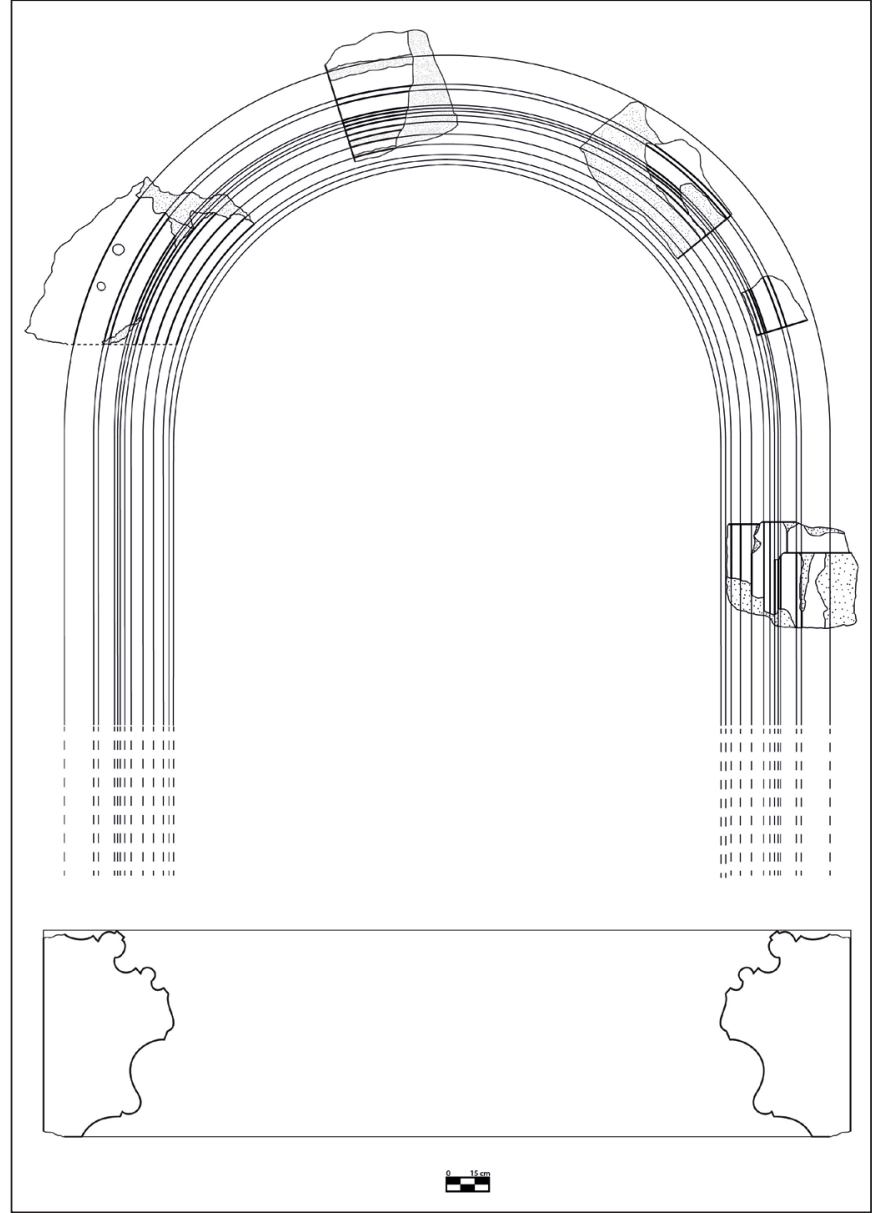

Fig. 10. Hypothetical reconstruction of the main gate, pt. 1

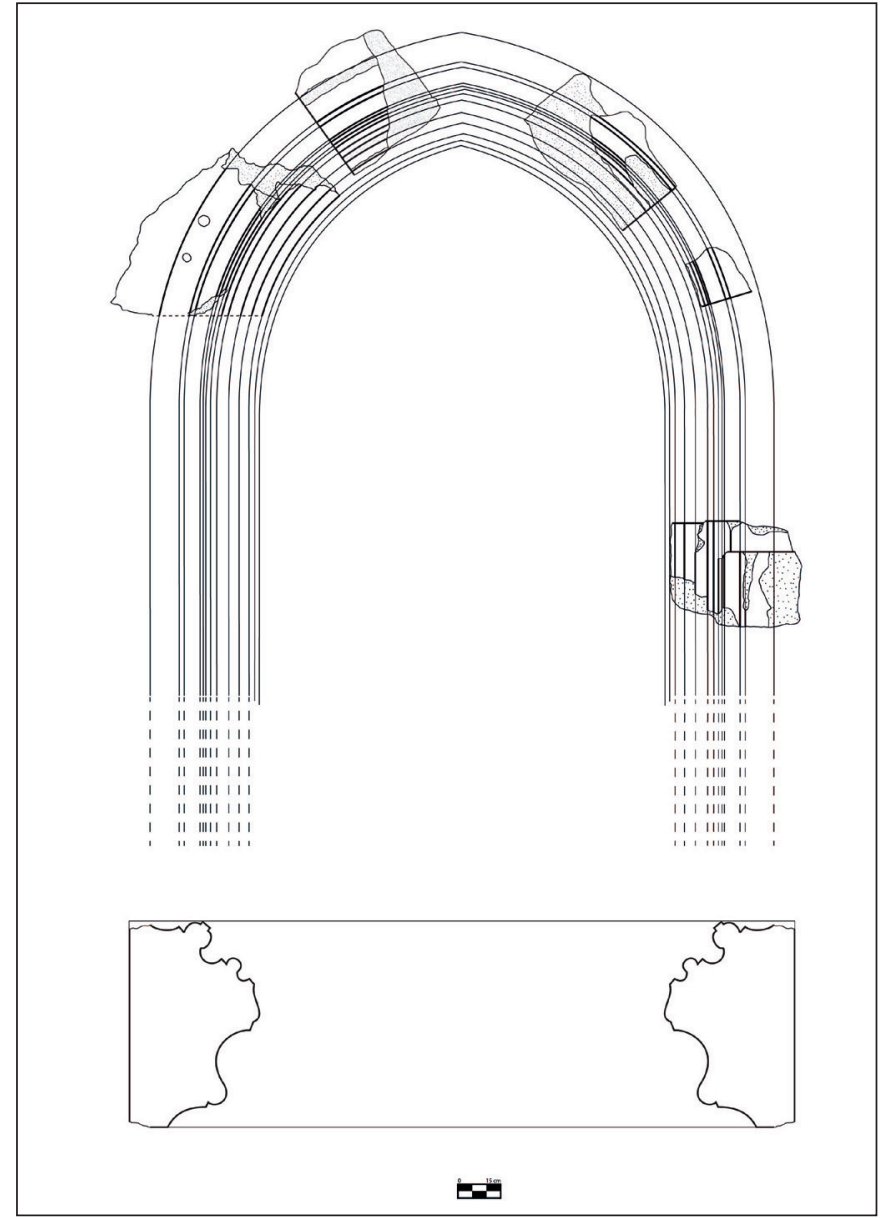

Fig. 11. Hypothetical reconstruction of the main gate, pt. 2

and 1.8 meters. Dating the frame is possible with the help of art history analogies. Two close analogies are known to me: the medieval (now western) gate of Ozora Castle (FELD \& Koppány 1987, 337, 343) and the castle gate of Kismarton (Eisenstadt) (Holzschun 1995). Both frames are from the early decades of the 15 th century, thus the main gate of Tata Castle most probably originates from the first building period.

The largest group of stone carvings contains 33 pieces, which all belonged to a single window frame. For most pieces, the exact place of finding is not known, but some were uncovered near the entirely destroyed south-western corner tower (marked with "V" in Fig. 1) and its vicinity (marked with "P" in Fig. 1) (Excavation report 1970). Additionally, some pieces were found on the Old Lake's northern bed. The different pieces could be distinguished based on their profile size and structure (Fig. 12). Thirteen carved stones belong to the stone frame, while there are nineteen horizontal and one vertical mullion pieces. The base of the frame stones was not found, only the vertical mullion's base could be identified. The fragments indicate that the mullion ended in a widened, twisted base, so the frame stones could have had similar bases as well. Two central axis, symmetric profiles were made on the largest and most important fragment (a frame stone) (No. 1 in Fig. 12). After this observation it became obvious

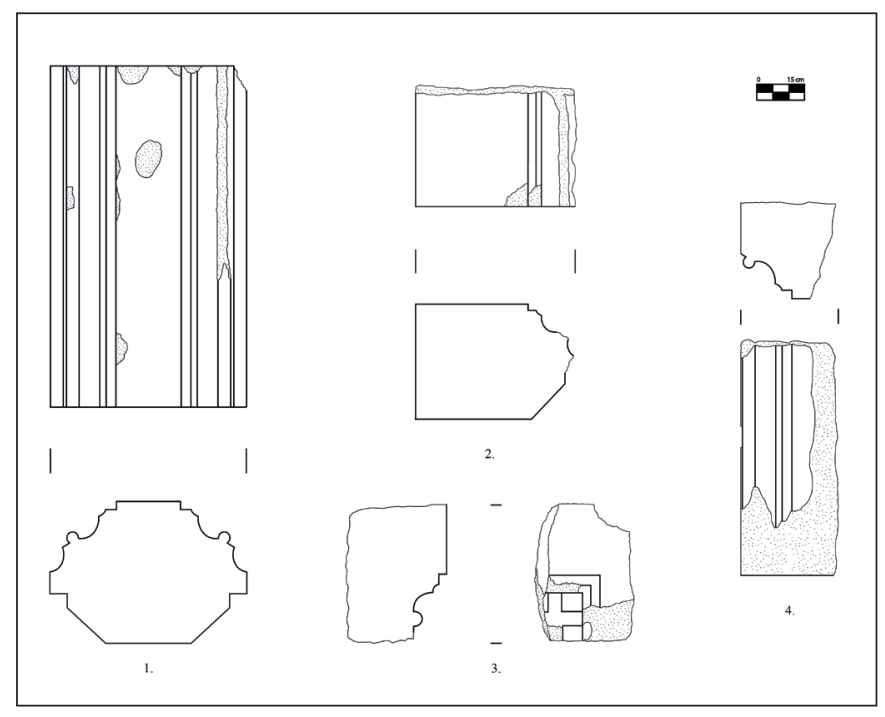

Fig. 12. Fragments of a Late Gothic double window 


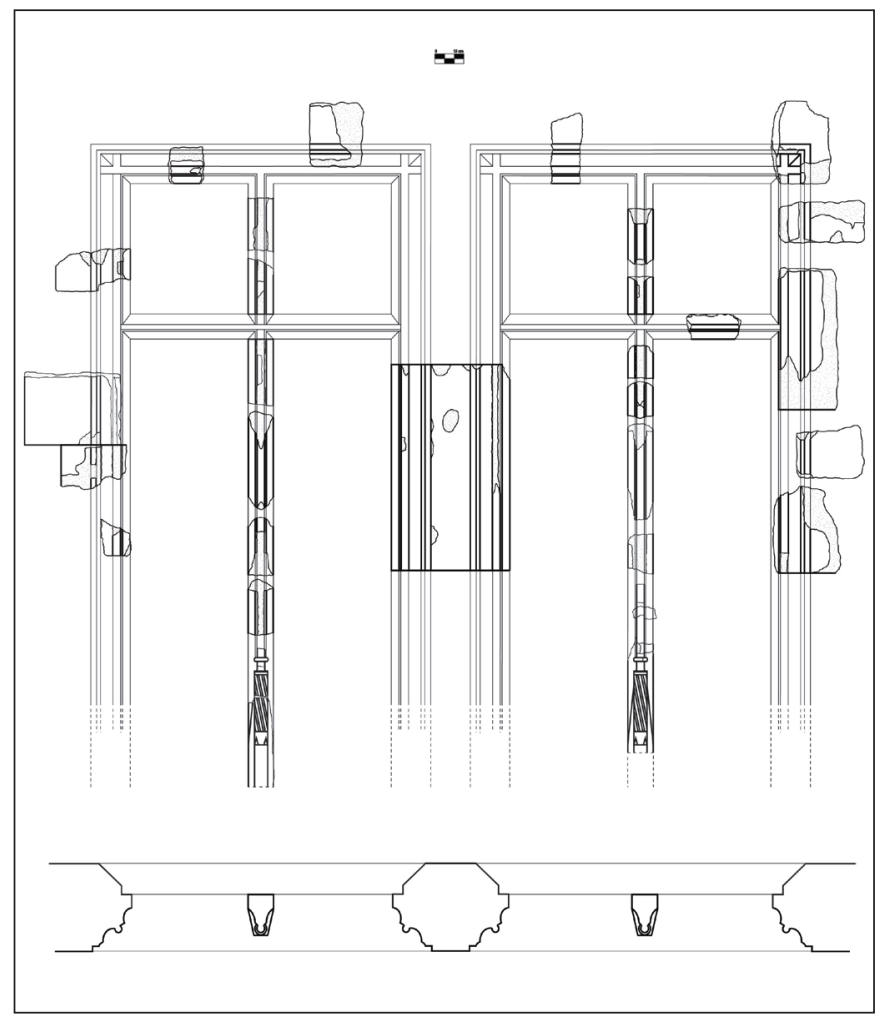

Fig. 13. Reconstruction of a Late Gothic double window

that this fragment belonged to a $2 \times 2$ window that had a single central frame stone. Despite the large number of fragments, the exact size of the original window frame is unknown, since the excavated finds are not suitable for an accurate estimation. Only the previously mentioned symmetric frame stone could be used as a point of reference, as it has no footing or a horizontal window section joining point, while the joints on both ends are smoothly carved. This suggests that the fragment must have been located between the horizontal window section and the footing. Despite these uncertainties I attempted to create the window frame's theoretical reconstruction (Fig. 13). Two similar window frames are known from this period: one from the Royal Palace in Visegrád (BuzÁs 1990, fig. 249) and another in the Bishop's castle in Györ (SEDLMAYR 1992, 52). However, these two are not $2 \times 2$, but $2 \times 4$ windows and their profiles are also different. They are similar in their locations though, as both were part of a bay window. The one from Visegrád was built during the reign of King Matthias, while the other from Györ was built by the monarch's trusted servant, Bishop Orbán of Nagylucse (SEDlmayr 1992, 52). Based on these findings, it is possible that a bay window was built during the second construction period of Tata Castle. The castle layout indicates a square-shaped structure from the second construction period, which was located outside the north-western corner tower. In my opinion, it might have been the foundation of a bay window as well. While it is only a hypothesis, I consider this note very important, despite the fact that a few window fragments were uncovered near the south-western corner tower (marked with "V" and "P" in Fig. 1). As mentioned before, the window profile from Tata Castle is unlike the other two bay window sections. However, it can be compared to other frames from the second half of the 15 th century. Such frames include three windows from the the Royal Palace in Visegrád (BuZÁs 1990, figs 239-241), along with others from Buda (Gerevich 1966, 285; fig. 405) and Esztergom (BuzÁs \& Tolnai 2004, 83-85; figs 5-8). Another window frame can be found in the Franciscan monastery of Szeged-Alsóváros, where the profile is almost identical to the double window from Tata Castle (LuKÁcs 2000, 176; figs 63-64). These parallels suggest that the $2 \times 2$ window frame from Tata Castle can be dated between the last quarter of the 15 th century and the first decade of the 16th century.

Finally, I would like to present the rich tracery patterns on the parapets, which are the most outstanding representative elements of the castle. Five Gothic parapet fragments can be identified, which once belonged to three different structures. The remains of a richly carved Gothic stone parapet were uncovered from the northern wing's cellar (marked with "M" in Fig. 1) during the archaeological survey (Excavation report 1968). The fragments were restored, and two larger pieces could be reconstructed from them (Fig. 14). The restored fragments reveal that the parapet had two, ver-

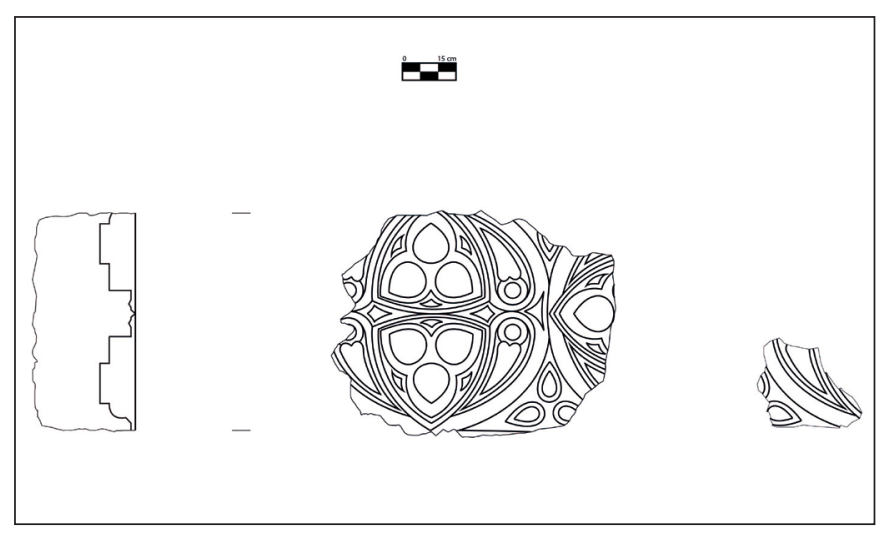

Fig. 14. Fragments of Balustrade No. 1 
Olivér Gillich $\bullet$ Architectural Elements of a Royal Residence. 15th Century Stone Carvings in Tata Castle

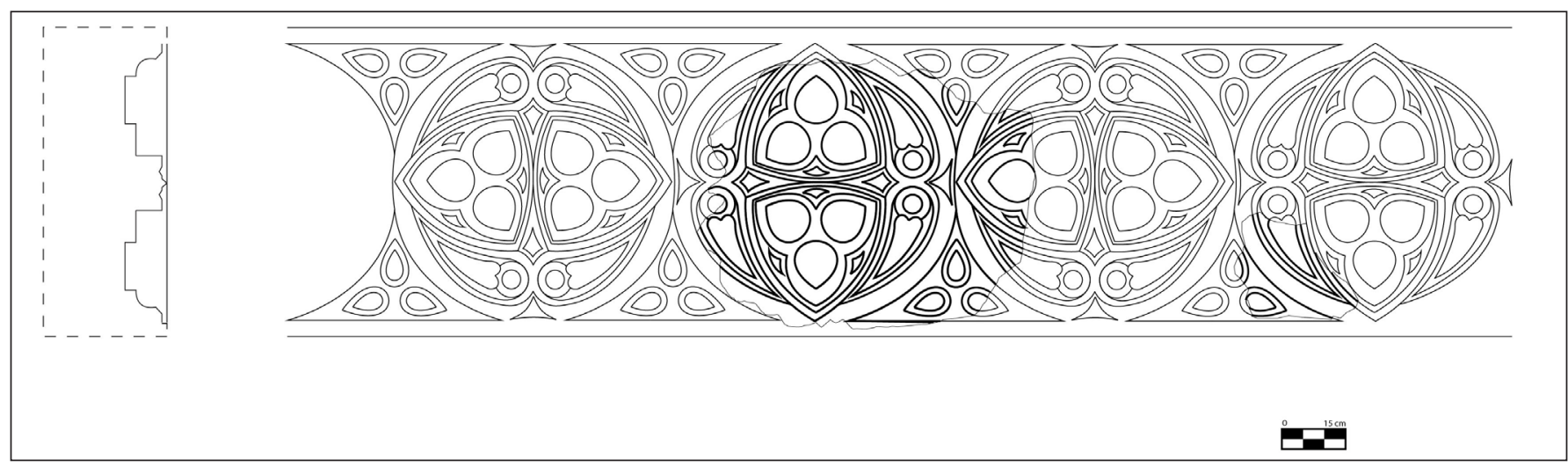

Fig. 15. Hypothetical reconstruction of Balustrade No. 1

tically mirror-symmetrical trefoils and an ornament shaped from four fish-bladders, which are set within a circle-shaped pane. Parapet analogies include Bratislava Castle and the western gallery of the Stephansdom in Vienna (MARosi 1983, 308-309). Based on these fragments, an illustration could be made of the reconstruction (Fig. 15). Despite having been uncovered from the northern castle-wing, the parapet cannot be clearly linked to this area, but it is also impossible to prove that it does not belong here. Fragments of two other parapets can also be found among archaeological finds. One (Fig. 10) was uncovered at the south-western tower (marked with "V" in Fig. 1) (Excavation report 1970), the other (No. 2 in Fig. 18) was found in the Old Lake. The third one's (No. 1 in Fig. 18) location is unknown. I could only make a reconstruction drawing of the former fragment (Fig. 17), which presumably had quatrefoil ornaments placed in two rows. This stone fragment is closely related to the parish church of Csütörtökhely, where the Late Gothic parapet in the chapel gallery was built during the second half of the 15th century (MAROSI 1987, 670). The other two related stone fragments also feature quatrefoil ornaments, however, due to their incomplete state I did not draw them. One of the three parapets most probably decorated the castle chapel's (marked with "F" in Fig. 1) upper gallery.

In summary it can be said that the heydays of Tata Castle were in the 15th century, which is further supported by archaeological finds and written records. I wanted to demonstrate the royal representative elements in the castle's architecture with the help of reconstructions based on carved stone pieces uncovered during the 1965-1972 excavations.

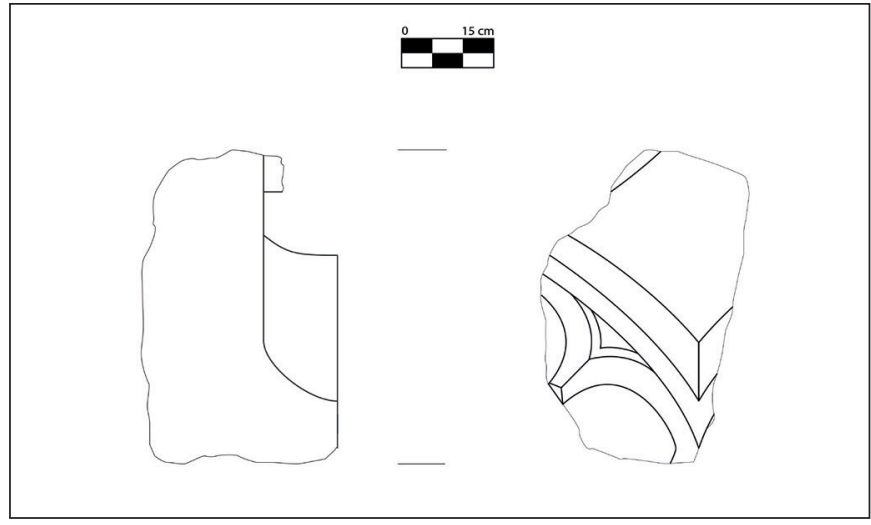

Fig. 16. Fragment of Balustrade No. 2

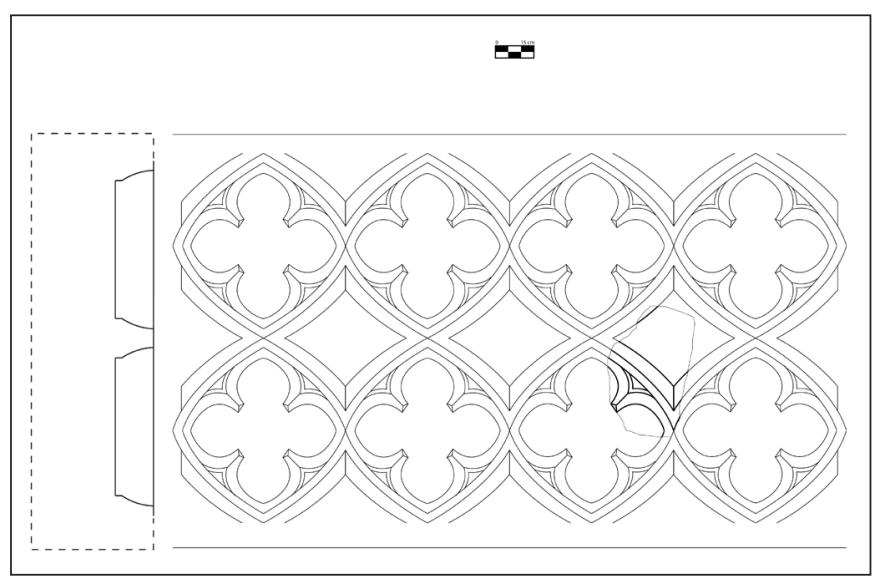

Fig. 17. Hypothetical reconstruction of Balustrade No. 2

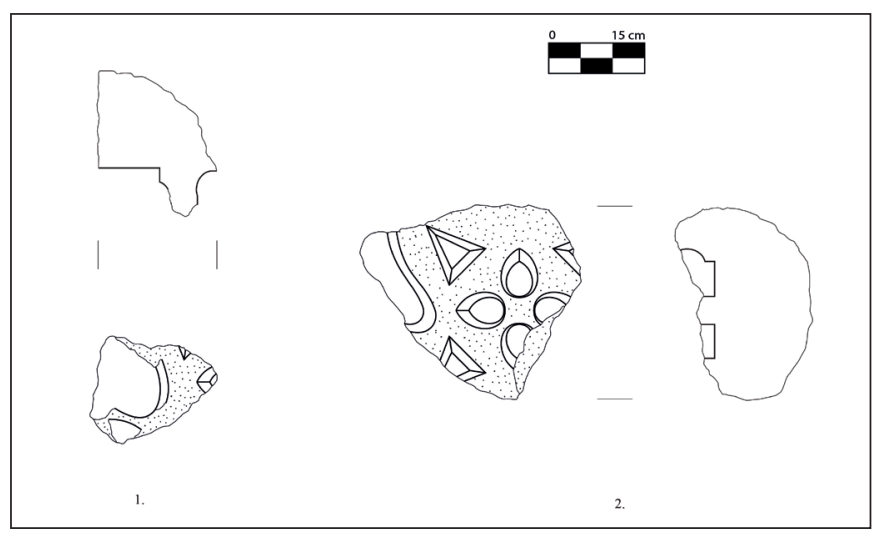

Fig. 18. Fragments of Balustrade No. 3 
Olivér Gillich • Architectural Elements of a Royal Residence. 15th Century Stone Carvings in Tata Castle

BIBLIOGRAPHY

B. Szatmári, S. (1974). Előzetes jelentés a tatai vár ásatásáról [Preliminary report in the excavations in Tata Castle]. Archaeologiai Értesítö 101, 45-53.

B. Szatmári, S. (1975). Tata. In Gerő László (ed.), Várépitészetünk. Budapest: Müszaki Könyvkiadó.

Buzás, G. (1990). Visegrád, királyi palota I. A kápolna és az északkeleti palota [Visegrád Royal Palace vol. I. The chapel and the northeastern palace]. Lapidarium Hungaricum. Magyarország építészeti töredékeinek gyüjteménye 2. Pest megye I. Budapest: Országos Müemléki Felügyelőség.

Buzás, G. (2008). Ballusztrádos loggiák a magyar kora reneszánsz építészetben [Loggias with balustrades in early Renaissance architecture in Hungary]. Castrum - A Castrum Bene Egyesület folyóirata 8, 71-108.

Buzás, G. (2010). A tatai vár 1510-ben [Tata Castle in 1510]. In János László (ed.), A diplomácia válaszútján. 500 éve volt Tatán országgyülés (pp. 93-113). Annales Tataienses 6. Tata: Tata Város Önkormányzata - Komárom-Esztergom Megyei Önkormányzat Múzeumainak Igazgatósága.

Buzás, G. \& Tolnai, G. (2004). Az Esztergomi Vármúzeum Kötárának katalógusa [Catalogue of the lapidarium in the Esztergom Castle Museum]. Az Esztergomi Vármúzeum Füzetei 2. Esztergom.

C. Tóth, N. (2010). Az út Tatáig. Országgyülések 1510-ben [The road to Tata. National assemblies in 1510]. In János László (ed.), A diplomácia válaszútján. 500 éve volt Tatán országgyülés (pp. 9-28). Annales Tataienses 6. Tata: Tata Város Önkormányzata - Komárom-Esztergom Megyei Önkormányzat Múzeumainak Igazgatósága.

Engel, P. \& C. Tóth, N. (2005). Királyok és királynék itinerárumai (1382-1438) [Itineraries of kings and queens]. Segédletek a középkori magyar történelem tanulmányozásához 1. Budapest: Magyar Tudományos Akadémia Támogatott Kutatóhelyek Irodája.

Engel, P. (1977). Királyi hatalom és arisztokrácia viszonya a Zsigmond korban [Relationship between royal power and aristocracy during the reign of Sigismund of Luxembourg]. Budapest: Akadémiai Kiadó.

Erdei, F. (1971). A tatai vár helyreállítása [The reconstruction of Tata Castle]. Müemlékvédelem Müemlékvédelmi és Épitészettörténeti Szemle 15 (2), 80-82.

Excavation reports, 1965-1972. Archive of the Kuny Domokos Museum.

Feld, I. \& Koppány, T. (1987). Az ozorai vár [The castle of Ozora]. In László Beke, Ernő Marosi \& Tünde Wehli (eds), Müvészet Zsigmond király korában 1387-1437. Tanulmányok 1. (pp. 332-346). Budapest: MTA Müvészettörténeti Kutatócsoport.

Gerevich, L. (1966). A budai vár feltárása [The excavation of Buda Castle]. Budapest: Akadémiai Kiadó.

Holzschuh, G. (1995). Zur Baugeschichte des Fürstlich Esterházyschen Schlosses in Eisenstadt. In J. M. Perschy (Hrsg.), Die Fürsten Esterházy. Ausstellungskatalog (pp. 144-155). Burgenländische Forschungen Sonderband 16. Eisenstadt.

Horváth, R. (2011). Itineraria regis Matthiae Corvini et reginae Beatricis de Aragonia (1458[1476]-1490). História Könyvtár, Kronológiák, Adattárak 12. Budapest: História - MTA Történettudományi Intézet. 
Olivér Gillich • Architectural Elements of a Royal Residence. 15th Century Stone Carvings in Tata Castle

Lukács, Zs. (2000). A Szeged-alsóvárosi ferences kolostoregyüttes [The Franciscan friary in SzegedAlsóváros]. In Tibor Kollár, István Bardoly \& Pál Lővei (eds), A középkori Dél-Alföld és Szer (pp. 143192). Dél-Alföldi Évszázadok 13. Szeged: Csongrád Megyei Levéltár.

Marosi, E. (1983). Buda és Vajdahunyad, a 15. századi magyarországi építészettörténet tartópillérei [Buda and Vajdahunyad, two pillars of 15th century architectural history]. Épités- Épitészettudomány 15, 293-310.

Marosi, E. (1987). Magyarországi müvészet 1300-1470 körül [Hungarian art around 1300-1470]. Budapest: Akadémiai Kiadó.

Neumann, T. (2010). A tatai vár és urai a Jagelló-korban [Tata Castle and its lords in the Jagiellon period]. In János László (ed.), A diplomácia válaszútján. 500 éve volt Tatán országgyülés (pp. 66-92). Annales Tataienses 6. Tata: Tata Város Önkormányzata - Komárom-Esztergom Megyei Önkormányzat Múzeumainak Igazgatósága.

Schmidtmayer, R. (2012). Vértesi várak. A Rozgonyi család fóúri rezidenciái a 15. században [Castles in Vértes. Aristocratic residences of the Rozgonyi family in the 15th century]. In Bence Péterfi, András Vadas, Gábor Mikó \& Péter Jakab (eds), Micae Mediaevales II. Fiatal történészek dolgozatai a középkori Magyarországról és Európáról. (pp. 123-140). Budapest: ELTE BTK Történelemtudományok Doktori Iskola.

Schönerné, P. I. (1968). A tatai vár 1569-72-böl származó alaprajza [Floor plan of the Tata Castle from 1569-72]. Komárom-Esztergom Megyei Múzeumok Közleményei 1, 263-272.

Sedlmayr, J. (1992). Késő gótikus zárt erkély a győri Püspökvárban [A late Gothic bay window in the Bishop's castle in Győr]. Müemlékvédelmi Szemle. Az Országos Müemléki Felügyelöség tájékoztatója 1, $48-53$.

Tóth, S. (1998). A tatai vár ostromának szerepe a 15 éves háborúban [The role of the siege of Tata in the Fifteen Years’ War]. In: János Fatuska, Éva Mária Fülöp \& László Gyüszi Jr. (eds), Annales Tataienses I. Tata a tizenöt éves háborúban. (pp. 19-44). Tata: Mecénás Közalapítvány. 